\title{
Risk Assessments in Construction of Water Supply Projects in Hanoi, Vietnam
}

\author{
Minh Thanh Nguyen', Sy Hung Mai2*, Quoc Hung Vu2* \\ ${ }^{1}$ Ministry of Construction, Hanoi, Vietnam \\ ${ }^{2}$ Department of Hydraulic Engineering and Construction, National University of Civil Engineering, Hanoi, Vietnam \\ Email: *minhthanhctn@gmail.com, „hungms@nuce.edu.vn, *hungvq@nuce.edu.vn
}

How to cite this paper: Nguyen, M. T., Mai, S. H., \& Vu, Q. H. (2021). Risk Assessments in Construction of Water Supply Projects in Hanoi, Vietnam. American Journal of Industrial and Business Management, $11,232-250$

https://doi.org/10.4236/ajibm.2021.112015

Received: January 5, 2021

Accepted: February 23, 2021

Published: February 26, 2021

Copyright $\odot 2021$ by author(s) and Scientific Research Publishing Inc. This work is licensed under the Creative Commons Attribution International License (CC BY 4.0).

http://creativecommons.org/licenses/by/4.0/

\begin{abstract}
Water is one of the developments that Vietnamese government has already committed and this sector always plays an important role in socio-economic life of Vietnam. The Government and Vietnamese people have been trying to improve infrastructure, enhance living standards for people and national socio-economic development. However, in terms of water, Vietnam still has to face many challenges that require a lot of efforts to deal with. Now, in Hanoi, especially the outskirts of the city, there is a huge lack of water works, causing negative impacts on community's life and the quality of environment. Water distribution systems play a critical role in supplying sufficient water to users with acceptable quantity, pressure, and quality. Risk assessment has been recognized as a useful tool to identify the hazard, analyse vulnerabilities, and risks, and select proper mitigation measures. A questionnaire has been designed including 51 factors that create risk events that can occur during construction works implementation. Risk matrix was used as basis for quantitative risk analysis to determine the most critical risks which were a great impact on project and also to indicate moderate risks that must be taken into consideration. The study analysis and assessment of risks are based on survey questionnaires, which achieved the following findings: 1 ) there are 26 main risks influencing schedule delays; 2) scientifically ranks influence every single risk on schedule delays; 3) making recommendations can reduce or eliminate influencing factors. This study provides a valuable reference which helps investors and contractors finish on schedule to ensure the benefits when building the Water Supply Projects.
\end{abstract}

\section{Keywords}

Risk Management, Risk Assessment, Water Supply System 


\section{Introduction}

Risk management has become a necessary requirement for construction projects. Risk matrix was used as basis for numerous countries. There are numerous factors that lead to slow construction progress of the contracting process (Doloi, Sawhney, Iyer, \& Rentala, 2012; Gündüz, Nielsen, \& Özdemir, 2013; Marzouk \& El-Rasas, 2014; McCord, McCord, Davis, Haran, \& Rodgers, 2015; Bagaya \& Song, 2016). A profound example of this is the Murali et al. through analysing reasons that cause delay of construction industry in Malaysia (Sambasivan \& Soon, 2007). The author presented the 10 most important causes of delay from a list of 28 different causes and 6 different effects of delay. In addition, Doloi et al. identified the key factors impacting delays in the Indian construction industry. It established the relationship between the critical attributes for developing prediction models for assessing the impacts of these factors on delays using questionnaires and personal interviews (Doloi, Sawhney, Iyer, \& Rentala, 2012).

Regarding the projects, despite its schedule delay, it is also influenced by a variety of factors that are different from various countries; previous researches have improperly focused on this topic. For instance, Wang et al. through evidence from Chinese construction companies, have quantitatively investigated the cause-effect relations among partnering, design management, and project outcomes which concluded that design management is critical to project performances (Wang, Tang, Qi, Shen, \& Huang, 2015). However, the research does not show mutual interactions amongst design, procurement, and construction risks. Shi et al. also presented a comprehensive assessment of investment risks for overseas power projects by establishing risk assessment model (Ge \& Shi, 2014).

Therefore, Wang et al. have presented 22 risk elements grouped into five groups including environment, technology, finance, and management to assess indicators of risks (Wang, Liu, \& Zhu, 2012). Liu et al. attempted the Carlo method to deal with random variables in order to manage financial risks, compensation, and financial management in construction process (Liu \& Song, 2010). However, detailed and accurate assessment of risks influencing projects is dependent on characteristics and developing level of a specific country. Assessment of the impact of risks is a complex problem, which must be approached systematically by breaking down the task into four stages that are risk classification, risk identification, risk analysis and risk response (Abd, 2015).

Efficient risk management is of the principal importance to water utilities. Three attributes are crucial to water users which that must be adequate quantities of water on demand, must be delivered at sufficient pressure and must be safe to use. Access to a reliable supply of drinking water and safe water quality are basic requirements of human health and economic development. In the third edition of the guidelines for drinking-water quality published by the World Health Organization (WHO), it is pointed out that a comprehensive risk man- 
agement approach is the most effective way to ensure the safety of drinking water supply.

Chan et al. (2014) identified and evaluated typical risks related to Public Private Partnership projects in the Chinese water supply sector. The discoveries displayed that completion risk, inflation, and price change risk have a higher impact on Chinese water public-private partnership projects. Roozbahani et al. (2013) studied risk assessment from tap to source of urban water supply systems that was usually subjected to a multiplicity of undefined threatening hazards. These threats differed to three main groups of natural, human-made, and operational hazards, which influence water quantity or water quality. Tchórzewska-Cieślak (2011) applied a fuzzy logic based method for risk assessment of drinking water system by defining the fuzzy rules between likelihood of pipe failures, consequence of failure, and sensitivity of water mains, drinking water technical system is an essential element of urban infrastructure. Wibowo and Mohamed (2010) investigated risk critically and allocation in privatized water supply projects in Indonesia and discussed the perception of regulator and operator in the term of project risk critically and allocation and both regarded to the principal concerned which was non-availability of raw water.

In order to evaluate the reliability of water supply systems under threatening conditions, risk assessment recognized as a useful tool to identify the hazard, analyse vulnerabilities, and risks. Therefore, the present paper aims to indicate most critical and significant risk factors that have a great influence on water supply projects. In addition, it aims to identify and assess risks during the construction of water supply projects and ratings of risk factors.

\section{Method Using in the Study}

In this study, a checklist method was used to survey participants who have experiences in construction of water supply projects in order to assess risks as well as impact level of them on constructions process.

The method using in the study is based on the questionnaire including risk elements impact on construction of water supply projects Hanoi-Vietnam.

In order to achieve main objective of this paper a review of the literature was conducted to investigate risk and identify the risk factors and sources in water supply system of construction project. Risk is assessed by qualitative risk management (RM) and one method of qualitative (RM) is questionnaires. The questionnaire used as a simple and effective way for purpose of data collection, it was consisted of two sections, risks factors associated to construction of water supply system and asked respondents to indicate the probability of occurrences of these risk factors and impact on construction of water supply system. These risk factors were sourced from a wide range of literature including journal paper and books worldwide as well as those specially focused on construction of water supply system.

The risks factors were categorized into groups of risk factors. The likert scale 
used for assessing probability and impact were from 1 to 5 where: $1=$ very low, 2 = low, 3 = moderate, $4=$ high, $5=$ very high. Forms of questionnaires created and distributed in water supply projects located in Hanoi city area. The survey data were statistically used for calculation of estimation parameters to analyse and assess the risk factors. The weak impact of risk elements will be eliminated if the estimated parameters do not satisfy required standard, and find the main risk have bad affect to construction process of water supply system.

More specifically, questionnaires were delivered to the participants who must have relevant work experience. To analyse and assess the risk elements, we establish the matrix from collected data of the questionnaires through a translation. From the questionnaires delivered by the surveyed members, we built a matrix with the size of $m \times n$ where $m$ is number of the surveyed members and $n$ is number of risk elements as follows:

$$
X=\left[\begin{array}{cccc}
x_{11} & x_{12} & \cdots & x_{1 n} \\
x_{21} & x_{22} & \cdots & x_{2 n} \\
\vdots & \vdots & \ddots & \vdots \\
x_{m 1} & x_{m 2} & \cdots & x_{m n}
\end{array}\right]
$$

In the established matrix, the impact levels, i.e., low; quite low; medium; high; and very high, are translated to corresponding numbers, i.e., 1, 2, 3, 4, and 5, respectively. We therefore obtained a commented matrix $X=x_{i j}$. Wherein, $x_{i j}$ stands for important meaning of comments given by the $i^{\text {th }}$ surveyed member on the $f^{\text {th }}$ risk element $(i=1,2, \cdots, m$ and $j=1,2, \cdots, n)$. Secondly, in the second step, i.e., analysis and assessment of the risks, we use the matrix that is established as described above to verify the accuracy of the risk variables model hypothesis based on necessary evaluation criteria using SPSS and AMOS commercial software, i.e., 1) Cronbach's Alpha coefficient to determine the reliability of the question; 2) Calculation and analysis discovery factors based on pattern matrix; 3) Analysis and verifying the combination of factors based on coefficients of loading factor.

\section{Results of Assessments}

\subsection{Identification of the Risks}

Inherit previous studies, the authors therefore summarize and initially establish a questionnaire including initial risk elements grouped into 7 main factors.

After obtaining an initial surveyed questionnaire with initial risk elements, in order to get a wide context and support for our arguments, the author used the table questionnaire interviews to 25 experts who have a lot of experiences in the field related to the construction of water supply projects to ask their views with respect to the reliability of the questionnaire, 25 supplementary interviews (experts including scientists in the construction of water supply projects, investors, design consultants, general contractors and subcontractors to gain their comments/criticisms). The author set up the questionnaire as follows:

In the questionnaire, as shown in Table 1 , the risk delay elements of the con- 
struction are divided into five levels, such as very low, low, medium, high and very high based on the risk impact. Besides, these levels were translated to the numbers corresponding to $1,2,3,4$ and 5 , respectively.

The questionnaires were delivered to the participants who must have relevant work experience to the construction of water supply projects, about 250. The participants required have relevant experience working. To ensure all questionnaires using in the study are accuracy, the authors verify and just use the questionnaire if all questions in which are answered correctly. Consequently, 227 surveyed questionnaires reach the requirement and they are used in the study, the aggregate number of respondent groups is described below.

There were 227 respondents, including 188 men (83\%) and 39 women (17\%). Ages 27 to 35 have 32 people (14\%) and ages 36 to 50 have 158 people (69\%), ages 51 to 60 have 37 people (17\%). 7 respondents were having Doctor degree (3\%), 20 respondents were having Master degree (9\%), 165 Bachelors (majority having civil engineering degree) (72\%) and 35 respondents was having other qualification (16\%). Moreover, 85 respondents were having experience ranging from 5 to 10 years (37\%) and remaining 142 had experience of more than 10 years (63\%). Overall 157 of them were designated as engineers (69\%), 59 as managers (26\%) and remaining 11 were academic professionals (5\%). Further, 85 respondents represented contractors (37\%), followed by Investor have 62 respondents (27\%), consultants have 64 respondents (28\%) and clients have 16 (7\%).

\subsection{Analysis and Assessment of the Risks}

In this part, we used surveyed data to statistically estimate parameters to analyse and assess risks. Obtained results are taken into comparison with the standard then causal factors with weak impact are eliminated. Thus, we find high impact causal factors.

\subsubsection{Calculation the Cronbach's Alpha}

Cronbach's alpha coefficient is used to determine the reliability of the question. It is well known that the Cronbach's alpha coefficient value $(\alpha)$ is always in the interval from zero to 1 . In addition, in case of $\alpha<0.6$ the hypothesis relating to the risk is unreliability, when $0.6<\alpha<0.8$ the former is reliability, while in the case of $0.8<\alpha<1$ the hypothesis is high reliability. For the surveyed data in this study, we use a condition of $\alpha>0.6$ to verify if the hypotheses corresponding to the risks are reliability (Hair et al., 2009). We can neglect the variables with $\mu<$ 0.3 , i.e., corrected item minus total correlation, which indicates those risks have a low impact level.

Calculate Cronbach's Alpha coefficient to determine the risk factor reliability $R 1$ :

From the result table in Table 2, there are a number of causal factors having "Corrected Item-Total Correlation $=\mu<0.3$ ", including. r1.2; r1.3; r1.4; r1.6; 
Table 1. Questionnaire using in the study.

\begin{tabular}{|c|c|c|c|c|c|c|c|}
\hline \multirow[b]{2}{*}{ Risk groups } & \multirow[b]{2}{*}{ Risk elements } & \multirow{2}{*}{$\begin{array}{c}\text { Expansions } \\
\text { of risks }\end{array}$} & \multicolumn{5}{|c|}{$\begin{array}{l}\text { Impact level bad to construction process of } \\
\text { water supply system }\end{array}$} \\
\hline & & & $\begin{array}{l}\text { Very } \\
\text { low } \\
(1)\end{array}$ & $\begin{array}{c}\text { Low } \\
(2)\end{array}$ & $\begin{array}{c}\text { Medium } \\
\text { (3) }\end{array}$ & $\begin{array}{l}\text { High } \\
(4)\end{array}$ & $\begin{array}{l}\text { Very } \\
\text { high } \\
(5)\end{array}$ \\
\hline \multirow{9}{*}{$\begin{array}{l}\text { Risks of } \\
\text { natural and } \\
\text { social factors } \\
\text { (R1) }\end{array}$} & Volatility in raw material prices & $\mathrm{r} 1.1$ & & & & & \\
\hline & Volatility in the labor market & $\mathrm{r} 1.2$ & & & & & \\
\hline & Fluctuations in the capital market & $\mathrm{r} 1.3$ & & & & & \\
\hline & Changes in factors of weather, climate, and natural disasters & $\mathrm{r} 1.4$ & & & & & \\
\hline & Policy changes & $\mathrm{r} 1.5$ & & & & & \\
\hline & Caused by topography and geology & r1.6 & & & & & \\
\hline & Cause of security & $\mathrm{r} 1.7$ & & & & & \\
\hline & $\begin{array}{l}\text { The reason is that the construction site is unfavorable, } \\
\text { overlapping with other works items }\end{array}$ & $\mathrm{r} 1.8$ & & & & & \\
\hline & Cause of the epidemic & r1.9 & & & & & \\
\hline \multirow{6}{*}{$\begin{array}{l}\text { Risks due to } \\
\text { contracts } \\
\text { (R2) }\end{array}$} & $\begin{array}{l}\text { The reason is the implicit transaction to sign the contract } \\
\text { (Collusion) }\end{array}$ & $\mathrm{r} 2.1$ & & & & & \\
\hline & Risk due to uncertain and unclear contract terms & $\mathrm{r} 2.2$ & & & & & \\
\hline & $\begin{array}{l}\text { The reason is due to changes or additions to the terms } \\
\text { of the contract }\end{array}$ & $\mathrm{r} 2.3$ & & & & & \\
\hline & $\begin{array}{l}\text { The reason is that the terms of responsibility of the two } \\
\text { parties are not clear }\end{array}$ & $\mathrm{r} 2.4$ & & & & & \\
\hline & The reason is the contract price adjustment clause & $\mathrm{r} 2.5$ & & & & & \\
\hline & Cause of contract dispute & $\mathrm{r} 2.6$ & & & & & \\
\hline \multirow{7}{*}{$\begin{array}{l}\text { Risks due to } \\
\text { economy } \\
\text { (R3) }\end{array}$} & Caused by the financial resources of the investor & $\mathrm{r} 3.1$ & & & & & \\
\hline & The reason is that the investor is slow to pay the contractor & $\mathrm{r} 3.2$ & & & & & \\
\hline & The reason is the financial capacity of the contractor & r3.3 & & & & & \\
\hline & $\begin{array}{l}\text { The reason is that the construction ground clearance } \\
\text { compensation is very complicated }\end{array}$ & $\mathrm{r} 3.4$ & & & & & \\
\hline & The reason due to risks on inflation & r3.5 & & & & & \\
\hline & The reason due to fluctuations in interest rates of bank & r3.6 & & & & & \\
\hline & The reason is changes in tax policies & r3.7 & & & & & \\
\hline \multirow{9}{*}{$\begin{array}{l}\text { Risks due to } \\
\text { project } \\
\text { management } \\
\text { (R4) }\end{array}$} & $\begin{array}{l}\text { The reason is that the construction project supervisor } \\
\text { is not good }\end{array}$ & $\mathrm{r} 4.1$ & & & & & \\
\hline & The reason is poor construction safety management & $\mathrm{r} 4.2$ & & & & & \\
\hline & $\begin{array}{l}\text { The reason is poor coordination of the investor and } \\
\text { general contractor }\end{array}$ & $\mathrm{r} 4.3$ & & & & & \\
\hline & The reason is the quality control of materials and materials & $\mathrm{r} 4.4$ & & & & & \\
\hline & The reason is poor management information system & $\mathrm{r} 4.5$ & & & & & \\
\hline & $\begin{array}{l}\text { The reason is not enough human resources to manage the } \\
\text { project }\end{array}$ & $\mathrm{r} 4.6$ & & & & & \\
\hline & The reason is that the staff's management capacity is not good & $\mathrm{r} 4.7$ & & & & & \\
\hline & The cause was due to the repair after the commissioning test & $\mathrm{r} 4.8$ & & & & & \\
\hline & $\begin{array}{l}\text { The reason is poor access to operation management } \\
\text { technology }\end{array}$ & r4.9 & & & & & \\
\hline
\end{tabular}




\section{Continued}

\begin{tabular}{|c|c|c|}
\hline \multirow{7}{*}{$\begin{array}{l}\text { Risks due to } \\
\text { design } \\
\text { consulting } \\
\text { work } \\
\text { (R5) }\end{array}$} & $\begin{array}{l}\text { The reason is the capacity of construction supervision } \\
\text { consultancy }\end{array}$ & $\mathrm{r} 5.1$ \\
\hline & Cause of the capacity of the design consultant & $\mathrm{r} 5.2$ \\
\hline & $\begin{array}{l}\text { The reason is that using typical design drawings lack of } \\
\text { actual correction }\end{array}$ & $\mathrm{r} 5.3$ \\
\hline & The reason was incorrect use of Technical Standards & r5.4 \\
\hline & $\begin{array}{l}\text { The reason is that using the job code in the incorrect } \\
\text { estimation }\end{array}$ & $\mathrm{r} 5.5$ \\
\hline & $\begin{array}{l}\text { The reason is that the calculation of the quantity of } \\
\text { materials of the consultant is incorrect }\end{array}$ & r5.6 \\
\hline & The reason is due to the field experiment & r5.7 \\
\hline \multirow{6}{*}{$\begin{array}{l}\text { Risks due to } \\
\text { the } \\
\text { contractor's } \\
\text { construction } \\
\text { capacity } \\
\text { (R6) }\end{array}$} & The reason is the construction crew's capacity & $\mathrm{r} 6.1$ \\
\hline & $\begin{array}{l}\text { The cause was investment in purchasing unsynchronous } \\
\text { and poor-quality equipment }\end{array}$ & $\mathrm{r} 6.2$ \\
\hline & $\begin{array}{l}\text { The reason is the weak technical capacity of the } \\
\text { general contractor }\end{array}$ & r6.3 \\
\hline & The reason is poor technical skills and human resources & $\mathrm{r} 6.4$ \\
\hline & The reason is not enough technical manpower & r6.5 \\
\hline & The reason is poor finished product & $\mathrm{r} 6.6$ \\
\hline \multirow{7}{*}{$\begin{array}{l}\text { Risks due to } \\
\text { administrative } \\
\text { and legal } \\
\text { procedures } \\
\text { (R7) }\end{array}$} & $\begin{array}{l}\text { The reason is that the construction unit lacks } \\
\text { understanding of law }\end{array}$ & $\mathrm{r} 7.1$ \\
\hline & $\begin{array}{l}\text { The reason is the relationship of the investor, the contractor } \\
\text { with the competent agency to the project }\end{array}$ & $\mathrm{r} 7.2$ \\
\hline & The reason is local construction management regulations & $\mathrm{r} 7.3$ \\
\hline & The reason is complicated administrative procedures & r7.4 \\
\hline & $\begin{array}{l}\text { The reason is the adjustment of the project's scale } \\
\text { of the investor }\end{array}$ & r7.5 \\
\hline & Causes of labor safety. & r7.6 \\
\hline & The cause is due to changes in laws, regulations, standards, ... & $\mathrm{r} 7.7$ \\
\hline \multirow{2}{*}{$\begin{array}{l}\text { Consequences } \\
\text { of the risk } \\
\text { factors }\end{array}$} & Prolong the construction progress & $(\mathrm{r} 8.1)$ \\
\hline & Increasing construction costs & $(\mathrm{r} 8.2)$ \\
\hline
\end{tabular}

r1.7; corrected item minus total correlation, which indicates those risks have a low impact level.

In Table 3, the Cronbach Alpha result when removing the risks with little effect The Cronbach Alpha of the R1 group was: 0.886. Thus, $0.8<\alpha<0.1$ is highly reliable (Hair et al., 2009).

Risks that have a major impact on the progress of this group include: r1.1, r1.5, r1.8, r1.9.

In the same way for other groups of risks, we find high impact causal factors:

As we can see in Table 4, all of the Cronbach's alpha coefficients are larger than $0.6(\alpha>0.6)$, indicating all results are reliable. 
Table 2. Results of Cronbach Alpha without removing causes had little effect.

\begin{tabular}{ccccc}
\hline Risk & $\begin{array}{c}\text { Scale Mean if Item } \\
\text { detected }\end{array}$ & $\begin{array}{c}\text { Scale variance if } \\
\text { Itemp detected }\end{array}$ & $\begin{array}{c}\text { Corrected } \\
\text { Item-Total } \\
\text { correlation }\end{array}$ & $\begin{array}{c}\text { Cronbach's Alpha } \\
\text { if Item detected }\end{array}$ \\
\hline r1.1 & 26.22 & 11.205 & 0.552 & 0.462 \\
r1.2 & 26.93 & 12.809 & 0.298 & 0.540 \\
r1.3 & 27.06 & 14.320 & 0.027 & 0.617 \\
r1.4 & 26.20 & 15.189 & 0.97 & 0.654 \\
r1.5 & 26.20 & 11.339 & 0.564 & 0.463 \\
r1.6 & 26.13 & 15.254 & 0.87 & 0.640 \\
r1.7 & 26.93 & 12.809 & 0.298 & 0.540 \\
r1.8 & 26.17 & 11.205 & 0.542 & 0.464 \\
r1.9 & 26.19 & 11.491 & 0.540 & 0.471 \\
\hline
\end{tabular}

Cronbach Alpha without removing causes had little effect: 0.58 .

Table 3. Cronbach Alpha results when eliminating 5 risks had little effect.

\begin{tabular}{ccccc}
\hline Risk & $\begin{array}{c}\text { Scale Mean if Item } \\
\text { detected }\end{array}$ & $\begin{array}{c}\text { Scale variance if } \\
\text { Itemp detected }\end{array}$ & $\begin{array}{c}\text { Corrected } \\
\text { Item-Total } \\
\text { correlation }\end{array}$ & $\begin{array}{c}\text { Cronbach's Alpha } \\
\text { if Item detected }\end{array}$ \\
\hline r1.1 & 10.70 & 5.372 & 0.805 & 0.831 \\
r1.5 & 10.68 & 6.633 & 0.776 & 0.843 \\
r1.8 & 10.65 & 5.821 & 0.659 & 0.888 \\
\hline
\end{tabular}

Cronbach Alpha results when eliminating 5 risks had little effect: 0.886 .

\subsubsection{Calculation and Analysis Discovery Factors Based on Pattern Matrix}

To analyse discovery factors based on pattern matrix, we base value indicators:

Kaiser-Meyer-Oklin (KMO), Bartlett examination $(\sigma)$, percentage of variance, coefficients calculated of loading factor to determine the risk factor group. $\mathrm{Ne}$ cessary to calculate and analyse the discovery factors in order to investigate the main factors including the observation variables (survey questions). In the factor analysis of SPSS software, the factor reduction method "principal axis factoring" and the horizontal rotation method "promax" are used. We then obtain results including seven factors from R1 to R7. Surveyed data are suitable to analyse risk factors if $\mathrm{KMO} \geq 0.5$ and $\sigma \leq 0.05$ indicates that surveyed data are statistics significance (Hair et al., 2009). Bartlett examination is a statistical value using to verify if variables possessing interaction effect. In case of Bartlett examination, i.e., $\sigma$ is smaller than 0.05 , variables possess interaction effect.

Results of KMO, $\sigma$ and percentage of variance reached:

Surveyed data are suitable to analyse risk factors if $\mathrm{KMO} \geq 0.5$, and $\sigma<0.05$ indicates that surveyed data are statistics significance (Hair et al., 2009). Bartlett examination is a statistical value using to verify if variables possessing interaction effect. 
Table 4. Calculation summary table Cronbach's Alpha.

\begin{tabular}{|c|c|c|c|c|}
\hline Risk groups & $\begin{array}{l}\text { Cronbach's } \\
\text { alpha Ri }\end{array}$ & $\begin{array}{l}\text { High-impac } \\
\text { t causes }\end{array}$ & $\begin{array}{l}\text { Cronbach's } \\
\text { alpha Ri }\end{array}$ & $\begin{array}{l}\text { Causes that } \\
\text { have a small } \\
\text { impact } \\
\text { (eliminated) }\end{array}$ \\
\hline $\begin{array}{l}\text { Risks of natural and social } \\
\text { factors } \\
\text { (R1) }\end{array}$ & 0.886 & $\begin{array}{l}\mathrm{r} 1.1 \\
\mathrm{r} 1.5 \\
\mathrm{r} 1.8 \\
\mathrm{r} 1.9\end{array}$ & $\begin{array}{l}0.831 \\
0.843 \\
0.888 \\
0.847\end{array}$ & $\begin{array}{l}\mathrm{r} 1.2 ; \mathrm{r} 1.3 ; \\
\mathrm{r} 1.4 ; \mathrm{r} 1.6 ; \\
\quad \mathrm{r} 1.7\end{array}$ \\
\hline $\begin{array}{l}\text { Risks due to contracts } \\
\text { (R2) }\end{array}$ & 0.852 & $\begin{array}{l}\mathrm{r} 2.1 \\
\mathrm{r} 2.2 \\
\mathrm{r} 2.6\end{array}$ & $\begin{array}{l}0.656 \\
0.981 \\
0.681\end{array}$ & $\begin{array}{l}\mathrm{r} 2.3 ; \mathrm{r} 3.4 ; \\
\mathrm{r} 3.5\end{array}$ \\
\hline $\begin{array}{l}\text { Risks due to economy } \\
\text { (R3) }\end{array}$ & 0.814 & $\begin{array}{l}\text { r3.2; } \\
\text { r3.3; } \\
\text { r3.4; } \\
\text { r3.5 }\end{array}$ & $\begin{array}{l}0.704 \\
0.822 \\
0.825 \\
0.701\end{array}$ & $\begin{array}{l}\mathrm{r} 3.1 ; \mathrm{r} 3.6 ; \\
\quad \mathrm{r} 3.7\end{array}$ \\
\hline $\begin{array}{l}\text { Risks due to project } \\
\text { management } \\
(\mathrm{R} 4)\end{array}$ & 0.900 & $\begin{array}{l}\mathrm{r} 4.1 \\
\mathrm{r} 4.3 \\
\mathrm{r} 4.6 \\
\mathrm{r} 4.9\end{array}$ & $\begin{array}{l}0.862 \\
0.872 \\
0.876 \\
0.873\end{array}$ & $\begin{array}{l}\mathrm{r} 4.2 ; \mathrm{r} 4.4 \\
\mathrm{r} 4.5 ; \mathrm{r} 4.7 \\
\quad \mathrm{r} 4.8\end{array}$ \\
\hline $\begin{array}{l}\text { Risks due to design consulting } \\
\text { work } \\
\text { (R5) }\end{array}$ & 0.718 & $\begin{array}{l}\mathrm{r} 5.2 \\
\mathrm{r} 5.5 \\
\mathrm{r} 5.6 \\
\mathrm{r} 5.7\end{array}$ & $\begin{array}{l}0.710 \\
0.645 \\
0.667 \\
0.598\end{array}$ & $\begin{array}{l}\text { r5.1; r5.3; } \\
\text { r5.4 }\end{array}$ \\
\hline $\begin{array}{l}\text { Risks due to the contractor's } \\
\text { construction capacity } \\
\text { (R6) }\end{array}$ & 0.872 & $\begin{array}{l}\text { r6.1; } \\
\text { r6.2; } \\
\text { r6.3; } \\
\text { r6.5 }\end{array}$ & $\begin{array}{l}0.813 \\
0.839 \\
0.864 \\
0.829\end{array}$ & $\mathrm{r} 6.4 ; \mathrm{r} 6.6$ \\
\hline $\begin{array}{l}\text { Risks due to administrative and } \\
\text { legal procedures } \\
\text { (R7) }\end{array}$ & 0.743 & $\begin{array}{l}\text { r7.4; } \\
\text { r7.5; } \\
\text { r7.6; } \\
\text { r7.7 }\end{array}$ & $\begin{array}{l}0.641 \\
0.727 \\
0.749 \\
0.605\end{array}$ & $\begin{array}{c}\text { r7.1; r7.2; } \\
\text { r7.3 }\end{array}$ \\
\hline
\end{tabular}

The KMO test coefficient features the value of $0.69(>0.5)$, indicating surveyed data are suitable to analyse factors, and the coefficient of the Bartlett statistical meaning is smaller than 0.00012 , i.e., $\sigma<0.05$, demonstrating variables possessing interaction effect. The data are effective for analysis conducting in the following steps.

As we can see in Table 5, seven factors were chosen, R1, R2, R3, R4, R5, R6, R7 whose percentage of variance reached $60.76 \%$, higher than the standard value of $50 \%$, these results mean that the risks grouping into seven groups is a reasonable hypothesis (Gerbing \& Anderson, 1988).

\section{Discussions and Implications to Reduce/Prevent Risks}

Based on the results obtained in Table 6, there are 21 risk factors that were analyzed to reduce/prevent risks. Hence, in this section, a process for risk control is developed and responded, in presented as below: 
Table 5. Total variance explanation.

\begin{tabular}{|c|c|c|c|c|c|c|c|}
\hline \multirow[t]{2}{*}{ Risks } & \multicolumn{4}{|c|}{ Initial Eigenvalues } & \multicolumn{2}{|c|}{$\begin{array}{l}\text { Extraction Sums of } \\
\text { Squared Loadings }\end{array}$} & \multirow{2}{*}{ 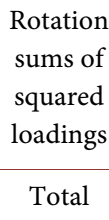 } \\
\hline & Total & Variance \% & Cumulation \% & Total & Variance $\%$ & Cumulation \% & \\
\hline 1 & 5.842 & 21.639 & 21.639 & 5.513 & 20.418 & 20.418 & 3.470 \\
\hline 2 & 2.883 & 10.676 & 32.315 & 2.585 & 9.573 & 29.990 & 3.462 \\
\hline 3 & 2.579 & 9.550 & 41.856 & 2.277 & 8.433 & 38.424 & 3.542 \\
\hline 4 & 2.211 & 8.190 & 50.056 & 1.840 & 6.816 & 45.240 & 3.377 \\
\hline 5 & 2.084 & 7.718 & 57.773 & 1.704 & 6.313 & 51.553 & 2.910 \\
\hline 6 & 1.677 & 6.212 & 63.985 & 1.272 & 4.711 & 56.263 & 2.689 \\
\hline 7 & 1.496 & 5.542 & 69.528 & 1.213 & 4.493 & 60.756 & 1.797 \\
\hline
\end{tabular}

\subsection{About the Problem Volatility in Raw Material Prices}

Firstly, the development of a coping strategy on material price fluctuations could be a solution to reduce risk of raw material cost; Secondly, selection criteria of supplying materials contractors such as prestige and financial capacity etc.. Particularly, it is necessary for constructors' commitment to no price change in certain time period.

\subsection{About the Policy Changes}

Participants in management must have a firm grasp of construction policies; Moreover, active plan for adapting a firm policy is great method to prevent risk of policy such as a good grasp of changing in new policies or establish a group of people who are responsible for observing policies of the authorities to apply in the project construction investment process.

\subsection{About the Reason Is that the Construction Site Is Unfavorable, Overlapping with Other Works Items}

To reduce risk of this factor, the investor and the general contractor should coordinate closely with the state management agency in the project construction area during project implementation. In addition, related parties have charge of handling the situation when an incident occurs during the construction of water supply projects. Also, an improvement in the quality survey and design work could be the best approach.

\subsection{On the Problem of Preventing Disease Causes}

Construction workers and supervisors often expose to harmful conditions such as strong sunlight, dust, air pollution etc. that can cause of healthy problems. Therefore, ensuring strict compliance with state regulations on disease prevention need to be carried out. Besides that, the epidemic prevention according to state regulations should be conducted under medical supervision; Moreover, 
Table 6. Synthesize the main causes of create risks factors.

\begin{tabular}{|c|c|c|}
\hline Risk groups & $\begin{array}{l}\text { High-impact } \\
\text { causes }\end{array}$ & Synthesize the main causes of create risks factors. \\
\hline $\begin{array}{l}\text { Risks of natural and social } \\
\text { factors } \\
\text { (R1) }\end{array}$ & $\begin{array}{l}\mathrm{r} 1.1 \\
\mathrm{r} 1.5 \\
\mathrm{r} 1.8 \\
\mathrm{r} 1.9\end{array}$ & $\begin{array}{l}\text { Volatility in raw material prices; } \\
\text { Policy changes; } \\
\text { The reason is that the construction site is unfavorable, overlapping with other works items; } \\
\text { Cause of the epidemic }\end{array}$ \\
\hline $\begin{array}{l}\text { Risks due to contracts } \\
\text { (R2) }\end{array}$ & $\begin{array}{l}\mathrm{r} 2.1 \\
\mathrm{r} 2.2 \\
\mathrm{r} 2.6\end{array}$ & $\begin{array}{l}\text { The reason is the implicit transaction to sign the contract (Collusion); } \\
\text { Risk due to uncertain and unclear contract terms; } \\
\text { Cause of contract dispute }\end{array}$ \\
\hline $\begin{array}{l}\text { Risks due to economy } \\
\text { (R3) }\end{array}$ & $\begin{array}{l}\text { r3.2; } \\
\text { r3.3; } \\
\text { r3.4; } \\
\text { r3.5 }\end{array}$ & $\begin{array}{l}\text { The reason is that the investor is slow to pay the contractor; } \\
\text { The reason is the financial capacity of the contractor; } \\
\text { The reason is that the construction ground clearance compensation is very complicated; } \\
\text { The reason due to risks on inflation }\end{array}$ \\
\hline $\begin{array}{l}\text { Risks due to project } \\
\text { management } \\
\text { (R4) }\end{array}$ & $\begin{array}{l}\mathrm{r} 4.1 \\
\mathrm{r} 4.3 \\
\mathrm{r} 4.6\end{array}$ & $\begin{array}{l}\text { The reason is that the construction project supervisor is not good; } \\
\text { The reason is poor coordination of the investor and general contractor; } \\
\text { The reason is not enough human resources to manage the project; } \\
\text { The reason is poor access to operation management technology }\end{array}$ \\
\hline $\begin{array}{l}\text { Risks due to design } \\
\text { consulting work } \\
\text { (R5) }\end{array}$ & $\begin{array}{l}\mathrm{r} 5.2 \\
\mathrm{r} 5.5 \\
\mathrm{r} 5.6 \\
\mathrm{r} 5.7\end{array}$ & $\begin{array}{l}\text { Cause of the capacity of the design consultant; } \\
\text { The reason is that using the job code in the incorrect estimation; } \\
\text { The reason is that the calculation of the quantity of materials of the consultant is incorrect; } \\
\text { The reason is due to the field experiment }\end{array}$ \\
\hline $\begin{array}{l}\text { Risks due to the contractor's } \\
\text { construction capacity } \\
\text { (R6) }\end{array}$ & $\begin{array}{l}\text { r6.1; } \\
\text { r6.2; } \\
\text { r6.3; } \\
\text { r6.5 }\end{array}$ & $\begin{array}{l}\text { The reason is the construction crew's capacity; } \\
\text { The cause was investment in purchasing unsynchronous and poor quality equipment; } \\
\text { The reason is the weak technical capacity of the general contractor; } \\
\text { The reason is not enough technical manpower }\end{array}$ \\
\hline $\begin{array}{l}\text { Risks due to administrative } \\
\text { and legal procedures } \\
\text { (R7) }\end{array}$ & $\begin{array}{l}\text { r7.4; } \\
\text { r7.5; } \\
\text { r7.6; } \\
\text { r7.7 }\end{array}$ & $\begin{array}{l}\text { The reason is complicated administrative procedures; } \\
\text { The reason is the adjustment of the project's scale of the investor; } \\
\text { Causes of labor safety; } \\
\text { The cause is due to changes in laws, regulations, standards }\end{array}$ \\
\hline
\end{tabular}

authorities in construction site should actively develop disease prevention scenarios such as divide the work shift, keep distance during construction, wear a mask, etc.

\subsection{About the Reason Is the Implicit Transaction to Sign the Contract (Collusion)}

Package constructions and bids must be announced widely and transparently to public on the mass media in accordance with the bidding law. Also, it is necessary to have inspection and supervision by competent units in organizing bidding, avoiding hook-up and bidding. If detecting a violation, it must be handled immediately according to law provisions.

\subsection{About the Reason Due to Uncertain and Unclear Contract Terms}

Investors and contractors have to release the contract forms as officially prescribed. Then, bilateral negotiation on contract terms must be conducted. In the 
contract, unclear and general terms should be avoided such as construction progress, construction quality and forms of payment in particular. Therefore, related parties into the contract must employ legal advisory in drafting and negotiating contracts to reduce risk of the factor.

\subsection{About Cause of Contract Dispute}

In construction process, if a dispute occurs, related parties in the contract must be reviewed firstly under the terms of the contract, particularly the specified term in relation to the dispute. To ensure no delay in the overall progress of the construction, the dispute should be deal with quickly and pleasurably. However, economic arbitration and court could be used finally in the case of disagreement dispute. Nevertheless, the investor should not substitute another contractor in any case.

\subsection{About the Reason Is That the Investor Is Slow to Pay the Contractor}

First of all, investors and contractors need to review the legal framework, ensure the consistency and consistency of the legal system on investment management, promptly remove barriers, difficulties, problems and create favorable conditions, accelerate disbursement progress and improve the efficiency of public investment projects. Then, investors and bidders must carry out check accountability of fund at each level of implementation to have sufficient basis for payment. Finally, related parties have to strengthen monitoring, inspection and implementation of the disbursement plan.

\subsection{About the Reason Is the Financial Capacity of the Contractor}

The evaluation of bidders must be carried out based on the bid evaluation criteria and other requirements in the bidding documents, on submitted bids, explanatory documents to ensure the selection of a qualified and experienced contractor with feasible solutions to execute the bidding package. As a result, selected bidder provides sufficient financial capacity to execute the bidding package. That is the best approach for risk management of financial capacity of the contractor. Besides, bank guarantee for contract advance, as well as advance payment must be required. It is necessary also to develop a monitoring solution to detect and promptly handle the bidders using advance payment for purposes out of the project or improper aims.

\subsection{About the Reason Is That the Construction Ground Clearance, Compensation Is Very Complicated}

The great corporation between investors and local authorities is primary factor in site clearance work. For construction process, the plan is divided into appropriate construction phase of each part, each item, make use of the clean space which has been cleared for construction. For residents, the investor needs to im- 
plement well the publicity and transparency of mechanisms, policies and interests of the people in site clearance, creating a basis for monitoring, helping residents for good resettlement with pleasure compensation.

\subsection{About the Reason Due to Risks on Inflation}

A risk on inflation is controlled in feasible projects due to inflation covered. During the preparation process, it is necessary to calculate and compare many options to find the most effective and optimal one that takes into account the price slippage problem. The inflation in the feasible project must be calculated in accordance with the strategic planning, general planning of each locality, each region, socio-economic conditions in the place where the construction will be built. The necessity, the investment form, the specific site selection options, the technology selection plan, the construction solution. construction, favorable difficulties must be determined clearly in feasible project. During construction process, the supply of raw materials, materials, energy, human resources in the process of later exploitation and operation, the cost of the work is stable product consumption, forecasting of price fluctuation in the near future.

\subsection{About the Reason Is That the Construction Project Supervisor Is Not Good}

In order to improve quality of construction, it is necessary to improve policies, and promulgate a number of separate regulations for large-scale projects or high technical requirements. Accordingly, the supervisor team is required highly criteria such as sufficient capacity, experience, responsibility and professional ethics, and prohibit collusion, bribery, and sharing with the contractor. In addition, the remuneration, salary need to be often adjusted and supplemented. However, the regulations on capacity conditions of investors and the role of the project supervisor leader must strictly comply to enhance their responsibilities with the monitoring agency in the field. As well as, it is considered about reports and comments of the supervision consultant from prior investor or authority to select appropriate supervision team.

\subsection{About the Reason Is Poor Coordination of the Investor and General Contractor}

The selection of reputable and experienced general contractors carried out many similar projects is one of methods to reduce risk of insufficient contractor capacity. Additionally, improving the quality of management board human resources of the investor is also another way. It is essential for both investors and bidders to be transparent and provide timely information to solve all problems about not enough human resources to manage the project.

\subsection{The Reason Is Not Enough Human Resources to Manage the Project}

This factor will be deal with sufficient bidder capacity. Accordingly, the good 
quantity of project managers such as enough experience and skill is provided appropriately for each discipline.

\subsection{About the Reason Is Poor Access to Operation Management Technology}

Technology is changing every day, thus corporation among investors, bidders and suppliers of equipment and technology could handle to reduce negative impacts on update new technology. For instance, technical suppliers should organize seminars about the technology related to the project, as well as invite investors to visit, improve training to grasp new technology regularly.

\subsection{About Cause of the Capacity of the Design Consultant}

Bid is the best method to select suitable design consultant for the construction project. Accordingly, an experienced consultant will be chosen through publicly and transparently suggested schedule project, including consulting elements, develop plan and check process, supervise the work quality of consulting contractor. Labors and experts must fulfill the standard criteria such as professional capability, profession, work experience, full license to perform work in accordance with the project. For design, surveys, image technical management, areas to set up survey outline, all elements, serving are required in detail via strengthening survey monitoring tools, checking survey at field implementation.

To ensure quality and acceleration, it is necessary to set up a regular meeting among investor board management, consultative verification and the design consultant to come up with mistake or design issues. Application for tools and terms into the consultant contract is required with capacity, experience in implementation and design treatment regime that does not guarantee quality. Also, the improvement of verifying quality with fully experienced and reputable is required. The verification contract should clearly define the requirements of the verification consultant's responsibility, the terms of handling quality violations, compensation for damage when the inspection results are not appropriate or not detected. Evaluation report must be clear, proportionate, detailed, not general.

\subsection{The Reason Is That Using the Job Code in the Incorrect Estimation}

It is essential to create a technical management system to control risks of this factor. For example, the verification work in accordance with regulations is conducted regularly, in particular, the verifying consultancy needs to carefully check the work code to advise timely adjustment.

\subsection{About the Reason Is That the Calculation of the Quantity of Materials of the Consultant Is Incorrect}

Inspecting, checking products such as construction material are required. Moreover, measuring and calculating construction volume when checking and accepting project formulation documents, construction design, construction cost 
estimates, payment and settlement of construction contracts, ensuring in terms of format etc. meet regulatory requirements.

Select consulting organizations and individuals who have the prescribed capacity and experience conditions to verify the construction volume at the request of the estimate-appraising agency or organization, total investment.

Performing the verification work in accordance with regulations, especially the verification unit needs to carefully check the calculation of the volume to advise timely adjustment.

\subsection{About the Reason Is Due to the Field Experiment}

Investor should organize the periodic monitoring and inspection of laboratory activities, field testing stations and strictly comply with the management of the field testing during the construction process according to Circular 04/2019/TT-BXD-Vietnam.

\subsection{About the Reason Is the Construction Crew's Capacity}

Firstly, the project management unit (PMU) needs to survey carefully before selecting construction crews. In addition, the workers must be trained and have professional certificates. Then, PMU should regularly inspect and replace workers who do not meet job requirements. Finally, security cameras are installed at the project construction area, increasing construction inspection.

\subsection{About the Cause Was Investment in Purchasing Unsynchronous and Poor-Quality Equipment}

PMU has to investigate carefully the capacity profile of the construction contractor before signing the contract. Moreover, the construction process is closely supervised, if the contractor does not fulfill requirement of the equipment, it could be made a penalty record or cancel the contract, find another contractor if necessary.

\subsection{About the Reason Is the Weak Technical Capacity of the General Contractor}

PMU has to investigate carefully the capacity profile of the construction contractor before signing the contract. The selection of general contractor is required following official policies such as bidder must use to implement at least 5 constructions of equivalent size or more comparison to the project. The more requirement of construction contractors is to improve technical capacity when necessary.

\subsection{About the Reason Is Not Enough Technical Manpower}

PMU has to investigate carefully the capacity profile of the construction contractor before signing the contract.

There are sanctions and handling measures when the contractor does not 
meet the manpower to implement the project. Additionally, inspecting and supervising construction personnel are required.

\subsection{About the Reason Is Complicated Administrative Procedures}

Coordination with stakeholders streamline and execute administrative issues quickly and properly through the process of examining the provincial legal documents related to the administrative reform, proposing to the competent authorities the amendment and annulment of the documents of central and local that are no longer appropriate. With the actual situation, the documents are expired or not in accordance with the documents of the superior state agencies.

Strengthen the application of modern technologies in administrative management, especially information technology in the process of receiving and processing dossiers, and special attention should be paid to the application of information technology in processing construction administrative content.

Strengthen the inspection and examination of the implementation of administrative procedures.

\subsection{About the Reason Is the Adjustment of the Project's Scale of the Investor}

The investor must have a plan to adjust the project scale. If the cause of the project scale change is proposed by the design consultant, the investor should associate with the verifying consultant and the appraisal agency to carefully consider the consultant's recommendations.

\subsection{About Causes of Labor Safety}

The investor must have a plan to adjust the project scale. If the cause of the project scale change is proposed by the design consultant, the investor should coordinate with authorities such as the appraisal consultant and the appraisal agency to carefully consider the consultant's recommendations. Also, time and finance should be modified to suit the new scale.

\subsection{About the Cause Is Due to Changes in Laws, Regulations, Standard}

The investor, together with the construction contractor, must have an occupational safety risk management plan, and have a project plan to handle if an accident or occupational safety incident occurs. This has important implications because the possibility of unsafe construction is entirely possible. When there are the initiative and timely handling measures, the site will not be disturbed and minimize the damage to people and property, and ensure the reputation of the contractor.

Warning signs and labor safety rules are arranged rationally. These signs should be in positions that can be easily seen and often seen by everyone.

For positions that may cause dangers on the construction site, the construc- 
tion unit is required to arrange instructors, perform the task of warning to prevent accidents for workers or residents.

Workers must be guaranteed with knowledge, labor protection, including clothes, shoes, hats, gloves and other necessary equipment.

\section{Conclusion}

Using the survey method, combined with statistical analysis, the study investigates potential risks influence on schedule delay of water projects in Hanoi-Vietnam. Findings in the study include:

1) The main causes that impact schedule construction projects were identified, and thereby the risk factor model was established for the water projects in Hanoi-Vietnam.

2) Based on those risk models the study has calculated, analysed, and evaluated carefully the risks to determine causes leading to the extension of construction progress of the project. The current study has revealed 7 risk factors group and 27 main causes that delay construction schedules of water projects in Hanoi-Vietnam.

3) Implications that could help contractors reduce/prevent and control those main causes were proposed.

This result has achieved the objective of the study. The findings of this study can be an excellent reference for project management teams to complete their construction project on schedule, and ensure the benefits to the government, the investor, the contractor, and the parties involved. The findings also can be applied in other countries which have similar economic and investment environment.

In this study, the risk assessment and control are constructed on the basis of survey data with experts, so the main source of data depends on the subjective experts' opinions. Therefore, it is proposed further studies on the following aspects:

1) In the aspect of engineering risk management information system, it is necessary to develop data collection and processing methods and standards, and to establish a risk-related information system in the construction process which can be adjusted to the specific conditions of each project.

2) It is needed to develop engineering risk management information system software to improve the implementation of project risk information management, and to extend the scope of management applications.

3) Study on application of these results to developing countries in the world, at the same time enhance the contribution to the international engineering management knowledge and draw lessons from the international project management practices.

\section{Conflicts of Interest}

The authors declare no conflicts of interest regarding the publication of this paper. 


\section{References}

Abd, A. M. (2015). Building Projects Risks Sources: Conceptual Fuzzy Assessment Approach. International Journal of Engineering Sciences \& Research Technology, 4, 325-332.

Bagaya, O., \& Song, J. (2016). Empirical Study of Factors Influencing Schedule Delays of Public Construction Projects in Burkina Faso. Journal of Management in Engineering, 32, Article ID: 05016014. https://doi.org/10.1061/(ASCE)ME.1943-5479.0000443

Chan, A. P., Lam, P. T., Wen, Y., Ameyaw, E. E., Wang, S., \& Ke, Y. (2014). Cross-Sectional Analysis of Critical Risk Factors for PPP Water Projects in China. Journal of Infrastructure Systems, 21, Article ID: 04014031. https://doi.org/10.1061/(ASCE)IS.1943-555X.0000214

Doloi, H., Sawhney, A., Iyer, K., \& Rentala, S. (2012). Analysing Factors Affecting Delays in Indian Construction Projects. International Journal of Project Management, 30, 479-489. https://doi.org/10.1016/j.ijproman.2011.10.004

Ge, S. J., \& Shi, A. N. (2014). Construction of the Factors Affecting China's Hydropower Projects and Overseas Investment Risk Assessment Index System. Applied Mechanics and Materials, 672, 2077-2084.

https://doi.org/10.4028/www.scientific.net/AMM.672-674.2077

Gerbing, D. W., \& Anderson, J. C. (1988). An Updated Paradigm for Scale Development Incorporating Unidimensionality and Its Assessment. Journal of Marketing Research, 25, 186-192. https://doi.org/10.1177/002224378802500207

Gündüz, M., Nielsen, Y., \& Özdemir, M. (2013). Quantification of Delay Factors Using the Relative Importance Index Method for Construction Projects in Turkey. Journal of Management in Engineering, 29, 133-139.

https://doi.org/10.1061/(ASCE)ME.1943-5479.0000129

Hair, J. F., Black, W. C., Babin, B. J., Anderson, R. E., \& Tatham, R. L. (2009). Análise Multivariada de Dados. Editora: Bookman.

Liu, D., \& Song, H. (2010). Risk Analysis and Comprehensive Evaluation of Risks in EPC Hydropower Engineering. Water Sciences and Engineering Technology, 1, 74-76.

Marzouk, M. M., \& El-Rasas, T. I. (2014). Analyzing Delay Causes in Egyptian Construction Projects. Journal of Advanced Research, 5, 49-55. https://doi.org/10.1016/j.jare.2012.11.005

McCord, J., McCord, M., Davis, P. T., Haran, M., \& Rodgers, W. J. (2015). Understanding Delays in Housing Construction: Evidence from Northern Ireland. Journal of Financial Management of Property and Construction, 20, 286-319. https://doi.org/10.1108/JFMPC-07-2015-0028

Roozbahani, A., Zahraie, B., \& Tabesh, M. (2013). Integrated Risk Assessment of Urban Water Supply Systems from Source to Tap. Stochastic Environmental Research and Risk Assessment, 27, 923-944. https://doi.org/10.1007/s00477-012-0614-9

Sambasivan, M., \& Soon, Y. W. (2007). Causes and Effects of Delays in Malaysian Construction Industry. International Journal of Project Management, 25, 517-526. https://doi.org/10.1016/j.ijproman.2006.11.007

Tchórzewska-Cieślak, B. (2011). Fuzzy Failure Risk Analysis in Drinking Water Technical System. Reliability: Theory \& Applications, 6 .

Wang, L., Liu, J.-L., \& Zhu, J.-W. (2012). Risk Evaluation of International EPC Hydropower Project Based on AHP-MF Model. Journal of Engineering Management, 4, 82-86.

Wang, T., Tang, W., Qi, D., Shen, W., \& Huang, M. (2015). Enhancing Design Management by Partnering in Delivery of International EPC Projects: Evidence from Chinese Construction Companies. Journal of Construction Engineering and Management, 142, 
Article ID: 04015099. https://doi.org/10.1061/(ASCE)CO.1943-7862.0001082

Wibowo, A., \& Mohamed, S. (2010). Risk Criticality and Allocation in Privatised Water Supply Projects in Indonesia. International Journal of Project Management, 28, 504-513. https://doi.org/10.1016/j.ijproman.2009.08.003 